\title{
Biological and ecological aspects of Xantusia sanchezi, an endangered lizard in an oak forest in the state of Jalisco, Mexico
}

\section{Aspectos biológicos y ecológicos de Xantusia sanchezi, una lagartija en peligro en un bosque de encino en el estado de Jalisco, México}

\author{
Daniel Cruz-Sáenz ${ }^{1,2} \otimes$ and David Lazcano ${ }^{2}$ \\ ${ }^{l}$ Centro de Estudios en Zoología, Centro Universitario de Ciencias Biológicas y Agropecuarias (CUCBA), Universidad de Guadalajara, Apartado \\ postal 1-1919, 44101 Guadalajara, Jalisco, México. \\ ${ }^{2}$ Laboratorio de Herpetología, Facultad de Ciencias Biológicas, Universidad Autónoma de Nuevo León, Apartado postal 513, 66450 San Nicolás de \\ los Garza, Nuevo León, México. \\ 凶dcruzsaenz@hotmail.com
}

\begin{abstract}
Xantusia sanchezi is an endangered species that is endemic to Mexico and is known only from the states of Jalisco and Zacatecas. We studied a population from a locality known as Huaxtla, in the municipality of Zapopan in the state of Jalisco. Sampling was conducted over a period of 7 months in an area of 1.5 hectares of grassland and oak forest with boulders. Collected data included: body measurements (total length, snout-vent length, tail length, head length, head width, head height, femur length, and femoral pores), sex, weight, habitat and average temperature and humidity. Habitat characterization was made using a coverage analysis. A total of 29 individuals were captured with 7 re-captures. This work provides the first data on the biology and ecology of this species, which is known in Jalisco from only a small area under tremendous threat due to urban development.
\end{abstract}

Key words: habitat, biometric, feeding.

\begin{abstract}
Resumen. Se realizó el estudio de una población de Xantusia sanchezi, una lagartija endémica de México y en peligro de extinción, que habita en los estados de Jalisco y Zacatecas. El muestreo se llevó a cabo por un periodo de 7 meses en una superficie de 1.5 hectáreas cuyo tipo de vegetación es pastizal con bosque de encino y afloramientos rocosos. El muestreo se efectuó en la localidad conocida como Huaxtla, ubicada en el municipio de Zapopan en el estado de Jalisco. Se tomaron diversos datos de los ejemplares, sexo, peso, hábitat y variables climáticas como temperatura y humedad. Además, se caracterizó el hábitat de la especie mediante el uso de análisis de las coberturas. Se registraron 29 ejemplares, algunos de estos fueron recapturados en distintas ocasiones. Este trabajo aporta datos sobre la biología y ecología de la especie, en una zona donde enfrenta fuertes presiones debido a los desarrollos habitacionales que se están construyendo y los que se tienen contemplados.
\end{abstract}

Palabras clave: hábitat, biometría, alimentación.

\section{Introduction}

Xantusia sanchezi is a small lizard that inhabits a limited area in the states of Jalisco and Zacatecas. It was described by Bezy and Flores-Villela in 1999 from the southern portion of the state of Zacatecas. It was reported for the state of Jalisco by Ponce-Campos et al. (2001) and from the locality of Huaxtla, Zapopan, Jalisco by CruzSáenz et al. (2008). X. sanchezi is the only species of the Xantusiidae that is known from the state of Jalisco (CruzSáenz et al., 2009; Fig. 1).

No information exists on the ecology, biology, distribution limits, and disjunct populations of this endemic species of Mexico. In addition, $X$. sanchezi is categorized by the Mexican NOM-ECOL-059-2001 (SEMARNAT, 2002), as being in danger of extinction. Like other night lizards, it is highly specialized and requires specific habitat conditions (Bezy, 1988), making it particularly vulnerable to habitat alternation. $X$. sanchezi lives under the bark of mesquite (Prosopis $s p$.) trees (Bezy and Flores-Villela, 1999), under the bark of oaks, and under rocks, in very rocky areas (PonceCampos et al., 2001). This is a small lizard; Bezy and Flores-Villela (1999) list $43 \mathrm{~mm}$ snout-vent-length (SVL) and $57 \mathrm{~mm}$ tail-length $\left(\mathrm{T}_{\mathrm{a}} \mathrm{L}\right)$ and Ponce-Campos et.al. (2001) pointed out that in Jalisco the lizards are slightly larger, measuring $50 \mathrm{~mm}(\mathrm{SVL})$ and $59 \mathrm{~mm}\left(\mathrm{~T}_{\mathrm{a}} \mathrm{L}\right)$. 


\section{Materials and methods}

Huaxtla is located in the northern part of the state of Jalisco, UTM 6644292315806 at 1458 meters of altitude within the municipality of Zapopan and located $20 \mathrm{~km}$ northwest of the metropolitan area of Guadalajara. This site is accessed by the Federal Highway \# 123 to Colotlán. The mountains belong to the Sierra de San Esteban and the dominant vegetation is oak forest, with some patches of tropical deciduous forest on a few slopes and in ravines. At the study site, 24 species of amphibians and reptiles coexist with $X$. sanchezi, 8 of these are protected by the Mexican NOM-ECOL-059-2001 (Cruz-Sáenz and Lazcano, 2010).

Our sampling occurred over a period of 7 months from September 2009 to March 2010. Intensive sampling was done within a polygon of 1.5 hectares, which was designated as the study area with grassland and boulders with rock crevices. The site was chosen based on prior information on this population by Cruz-Sáenz et al. (2008). The study site is located on a slope which is almost devoid of trees and shrubs, the surface being covered by various species of herbaceous plants, as well as a rocky outcrop. It is a cleared area that was previously used for agriculture purposes; the surrounding vegetation is awell preservedoak forest (Fig. 1).

Measurements taken for each individual were: total length (TL), snout-vent length (SVL), tail length $\left(\mathrm{T}_{\mathrm{a}} \mathrm{L}\right)$, head length (HL), head width (HW), head height $(\mathrm{HH})$, femur length (FL), femoral pores (FP), weight, sex, life stage (neonate, juvenile or adult). After taking the measurements all individuals were released in situ. Measurements were taken with a digital caliper AutoTECTM and biomass was determined using a digital Grobet ${ }^{\circledR}$ scale (used by jewelers).

Based on the total range in observed snout-vent length, we set up 3 stages with equal ranges: juvenile $25-35 \mathrm{~mm}$, adult I $36-45 \mathrm{~mm}$, and adult II $46-55 \mathrm{~mm}$.

Crevice width was measured with a digital caliper taking the narrowest point of the crevice, with the intention of determining the relationship between the width of crevice and that of the lizards. Sex was determined using the technique proposed by Davis and Leavitt (2007) and Brown (2009) with a Maglight ${ }^{\circledR}$ lamp model Minimaglite ${ }^{\circledR}$.

To characterize habitat structure, relevant variables were quantified (Greenberg et al., 1994 and Jellinek et al.,
2004) within a radius of $3 \mathrm{~m}$ of the capture site, including: percentage of rocks, shrubs, trees, herbaceous plants, bare ground, leaf litter, and fallen logs.

\section{Results}

After 7 months (September 2009-March 2010) of sampling and 21 field trips, 29 individuals were captured, with an additional number of 7 re-captures. Of the total individuals registered, 26 were females and 3 were males. All individuals were found in rock crevices within the study site, never under rocks.

Individuals were detected in an altitude gradient from 1402 to $1471 \mathrm{~m}$. At the moment of capture, temperature and measurements of the rock crevice were taken.

Based on the data, individuals had preferences for rock crevice temperature of $22.22{ }^{\circ} \mathrm{C}\left( \pm 5.02^{\circ} \mathrm{C}\right)$ and a width of $5.48 \mathrm{~mm}( \pm 1.09 \mathrm{~mm})$. Measurements for the 29 lizards captured are in Table 1.

The results of the habitat structure data for $X$. sanchezi show that this species has a preference for rocky areas, which was the predominant cover in each of the sites where individuals were found. Bare ground had less coverage (Fig. 2).

Incidental to our work we observed 2 instances of feeding. We observed one individual feeding on a Lepidoptera larva and another on a Argiope sp. spider (Cruz-Sáenz et al., in press).

\section{Discussion}

All individuals were found in rock crevices. This finding differs from that of Bezy and Flores-Villela (1999) in Zacatecas who found the species only under Prosopis bark, and that of Ponce-Campos et al. (2001), who observed individuals under oak bark or rocks at the locality known as El Diente in the municipality of Zapopan, Jalisco. Rock-crevice microhabitat has been reported for other species of Xantusia, such as X. henshawi (Lee, 1975), X. arizonae, X. bezyi, and X. sierrae (Bezy, 1988). The observed rock crevice preference could be attributed to the low concentration of trees within the site and the presence of a rocky outcrop. Whether the species

Table 1. Mean values of biometric measures of lizards with standard deviation (SD) on the right side of each measurement in the different stages

\begin{tabular}{ccccccccccc}
\hline Stage & $T L$ & $S V L$ & $T_{a} L$ & $F L$ & $H L$ & $H W$ & $H H$ & $F P$ & $W$ & ${ }^{\circ} C$ \\
\hline Juvenile & 74.24 & 33.53 & 40.71 & 5.00 & 8.72 & 5.57 & 3.37 & 11.57 & 1.10 & 27.16 \\
Adult I & 94.00 & 42.65 & 51.35 & 6.42 & 9.58 & 6.68 & 4.56 & 16.30 & 1.83 & 28.44 \\
Adult II & 104.96 & 49.28 & 55.67 & 6.73 & 10.81 & 7.33 & 4.23 & 16.75 & 2.56 & 27.94 \\
\hline
\end{tabular}




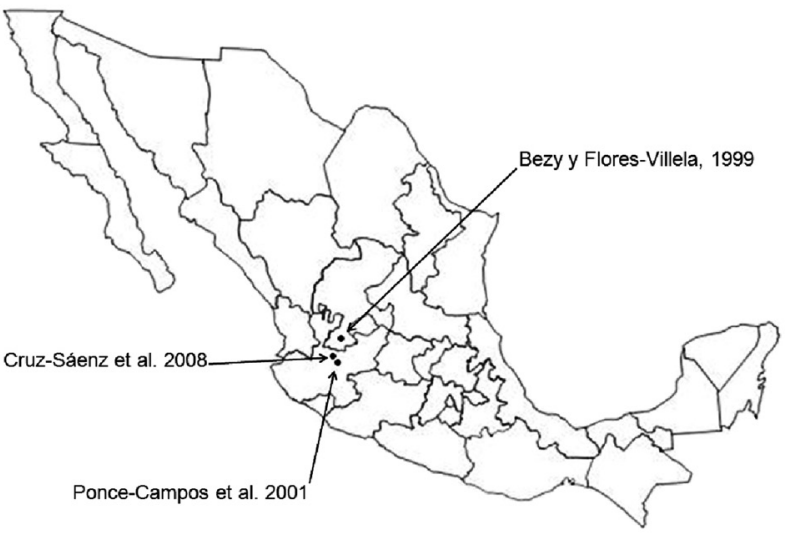

Figure 1. The 3 known localities for $X$. sanchezi.

is restricted to rock crevices within the oak forest remains to be determined.

All sampled individuals of $X$. sanchezi in the study were found in crevices, to which their flattened body is adapted. As mentioned by Cooper et al. (2000), crevices between rocks and other hard objects, as well as burrows in relatively hard soil, serve as refuges from predators in a wide variety of lizards. This would be the case for $X$. sanchezi, but depending on the physical characteristics of the crevices, snakes may have a better chance of preying on this lizard than mammals or birds (Cruz-Sáenz and Lazcano, 2010).

There were no significant differences between males and females in the biometric data, and whether sexual dimorphism exists in $X$. sanchezi requires further investigation. The flattened form of $X$. sanchezi and a number of the measurements taken such as: head length, width and height, appear to be correlated with width of crevices (Table 1).

Diet of this genus has been documented by Brattstrom (1952) who studied $X$. arizonae, $X$. henshawi and $X$. riversiana, and reported that they prey on a variety of food items, mainly on insects and spiders. $X$. riversiana also appears to be extensively herbivorous (Brattstrom, 1952; Fellers and Drost, 1991). Nothing has been published on the diet of $X$. sanchezi. We found individuals of $X$. sanchezi feeding on spiders and Lepidoptera larvae consistent with the previous studies (Cruz-Sáenz et al., in press).

Sierra San Esteban is the southern most known area of distribution of $X$. sanchezi, and is an exceptional site to study this species. Due to the fragmentation of this delicate habitat, which already has been altered to some degree, the few populations of Xantusia, surviving in the area, could be further isolated. The proximity of Sierra de San Esteban to the metropolitan area of Guadalajara adds additional

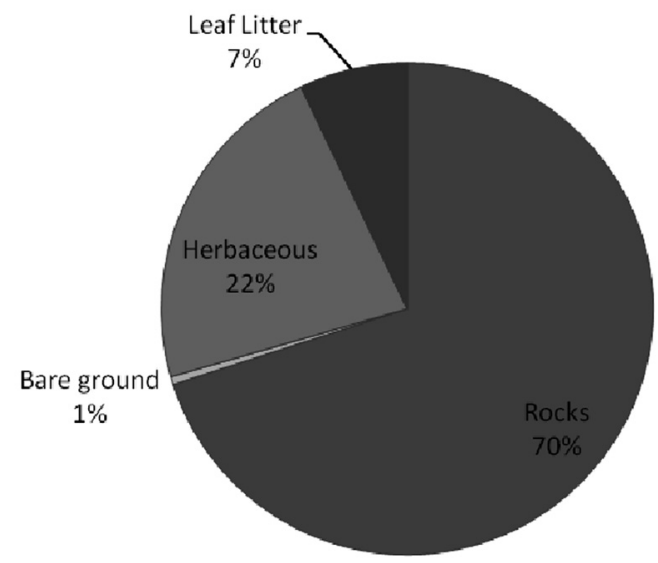

Figure 2. Percentage of coverage of different substrata in the habitat structure of $X$. sanchezi.

pressure to this ecosystem due to intensive urbanization, use by an increasing number of city visitors, causing the further isolation of remaining species of the flora and fauna.

\section{Acknowledgments}

To CONACYT for the supporting scholarship given to the main author CONACYT-229132 and SEMARNAT for issuing a collecting permit (SGP/DGVS/ 06423/09). We also thank the following persons for their participation in field work, Eduardo Gudiño-Larios and Edgar Flores-Covarrubias.

\section{Literature cited}

Bezy, R. L. 1988. The natural history of the night lizard's family Xantusiidae. In Proceedings of the conference on California herpetology. 1-12, H. F. DeLisle, P. R. Brown, B. Kaufman and B. M. McGurty (eds.). Southwestern Herpetologists Society Special Publication 4:1-143.

Bezy, R. L. and O. A. Flores-Villela. 1999. A new species of Xantusia (Squamata: Xantusiidae) from Zacatecas Mexico. Herpetologica 55:174-184.

Brattstrom, B. H. 1952. The food of the night lizards, genus Xantusia. Copeia 3:168-172.

Brown, D. 2009. Hemipenal transillumination as a sexing technique in Varanids. Biawak 3:26-29.

Cruz-Sáenz, D., E. Gudiño-Larios, C. D. Jimeno-Sevilla, R. López-Velázquez and J. Cortés-Aguilar. 2008. Guía de reptiles y anfibios de Arcediano. Comisión Estatal del Agua Jalisco. $126 \mathrm{p}$.

Cruz-Sáenz, D., S. Guerrero, D. Lazcano and J. Téllez-López. 2009. Notes on the Herpetofauna of the Western Mexico 1: The Herpetofauna of the State of Jalisco, Mexico. Bulletin of 
Chicago Herpetological Society 44:105-113.

Cruz-Sáenz, D. and D. Lazcano.2010. Notes on the Herpetofauna of Western Mexico 3: Herpetofauna sympatric with Xantusia sanchezi in an oak forest of Jalisco, Mexico. Bulletin of Chicago Herpetological Society 45:173-176.

Cruz-Sáenz, D, D. Lazcano and S. Guerrero-Vázquez. Xantusia sanchezi (Zacatecas night lizard). Diet. Herpetological Review (In press).

Cooper, W. Jr., J. H. Van Wyk, P. Le F. N. Mouton, A. M. AlJohany, J. A. Lemos-Espinal, M. A. Paulissen and M. Flowers. 2000. Lizard antipredatory behaviors preventing extraction from crevices. Herpetologica 56:394-401.

Davis, A. and D. Leavitt. 2007. Candlelight vigilis: A non invasive method for sexing small, sexually monomorphic lizards. Herpetological Review 38:402-404.

Fellers, G. M. and C. A. Drost. 1991. Ecology of the island night lizard, Xantusia riversiana, on Santa Barbara Island, California. Herpetological Monographs 5:28-78.

Lee, J. C. 1975. The autecology of Xantusia henshawi henshawi (Sauria: Xantusiidae). Transactions of the San Diego Society of Natural History 17:257- 277.

SEMARNAT. 2002. Norma Oficial Mexicana NOM-059ECOL-2001. Protección ambiental- Especies nativas de México de flora y fauna silvestres- Categorías de riesgo y especificaciones para su inclusión, exclusión o cambio- Lista de especies en riesgo. 